\title{
Net protein and metabolizable protein requirements for maintenance and growth of early-weaned Dorper crossbred male lambs
}

\author{
Tao Ma ${ }^{1} \mathbb{D}$, Kaidong Deng ${ }^{2}$, Yan Tu ${ }^{1}$, Naifeng Zhang ${ }^{1}$, Bingwen $\mathrm{Si}^{1}$, Guishan $\mathrm{Xu}^{1,3}$ and Qiyu Diao ${ }^{1 *}$
}

\begin{abstract}
Background: Dorper is an important breed for meat purpose and widely used in the livestock industry of the world. However, the protein requirement of Dorper crossbred has not been investigated. The current paper reports the net protein (NP) and metabolizable protein (MP) requirements of Dorper crossbred ram lambs from 20 to $35 \mathrm{~kg} \mathrm{BW.}$

Methods: Thirty-five Dorper $\times$ thin-tailed Han crossbred lambs weaned at approximately $50 \mathrm{~d}$ of age $(20.3 \pm 2$. $15 \mathrm{~kg}$ of BW) were used. Seven lambs of $25 \mathrm{~kg} \mathrm{BW}$ were slaughtered as the baseline animals at the start of the trial. An intermediate group of seven randomly selected lambs fed ad libitum was slaughtered at $28.6 \mathrm{~kg} \mathrm{BW}$. The remaining 21 lambs were randomly divided into three levels of dry matter intake: ad libitum or $70 \%$ or $40 \%$ of ad libitum intake. Those lambs were slaughtered when the lambs fed ad libitum reached $35 \mathrm{~kg}$ BW. Total body N and $\mathrm{N}$ retention were measured.

Results: The daily NP and MP requirements for maintenance were 1.89 and $4.52 \mathrm{~g} / \mathrm{kg}$ metabolic shrunk BW (SBW ${ }^{0.75}$ ). The partial efficiency of MP utilization for maintenance was 0.42 . The NP requirement for growth ranged from 12.1 to $43.5 \mathrm{~g} / \mathrm{d}$, for the lambs gaining 100 to $350 \mathrm{~g} / \mathrm{d}$, and the partial efficiency of MP utilization for growth was 0.86 .

Conclusions: The NP and MP requirements for the maintenance and growth of Dorper crossbred male lambs were lower than the recommendations of American and British nutritional systems.
\end{abstract}

Keywords: Growth, Lamb, Maintenance, Metabolizable protein, Net protein

\section{Background}

In the intensive livestock industry, protein is commonly the most expensive feed component and therefore, it is necessary to have a precise understanding of protein requirement of livestock not only to ensure farm profitability, but also to help reduce nitrogen $(\mathrm{N})$ emission to the environments [1]. Modern feeding systems, such as Agricultural and Food Research Council (AFRC) [2], Commonwealth Scientific and Industrial Research Organisation (CSIRO) [3], and National Research Council (NRC) [4], have reported protein and other nutrient

\footnotetext{
* Correspondence: diaoqiyu@caas.cn

${ }^{1}$ Feed Research Institute/Key laboratory of Feed Biotechnology of the Ministry of Agriculture, Chinese Academy of Agricultural Sciences, Beijing, China

Full list of author information is available at the end of the article
}

requirements of sheep, which are widely adopted for diet formulation in the world.

The Dorper is a popular sire breed for meat production in both South Africa and United States [5]. In recent years, Dorper sheep have been imported to China to improve the growth performance and carcass traits of indigenous breed, among which the thin-tailed Han sheep is one of the most famous native breeds with high prolificacy, as it carries mutations in both the $B M P R-1 B$ and $B M P 15$ genes [6]. Thus, the Dorper $\times$ thin-tailed Han crossbreed has become one of the dominant breeds for lamb meat production.

Our research team conducted a series of studies on the nutrient requirements (energy, protein, and minerals) of Dorper $\times$ thin-tailed Han crossbred sheep [7-9]. In this paper, we reported the protein requirements of 
male lambs after weaning ranging from 20 to $35 \mathrm{~kg} \mathrm{BW}$ by the comparative slaughter technique.

\section{Methods}

The current research was conducted from June to September 2011 at the Experimental Station of the Chinese Academy of Agricultural Sciences (CAAS), Nankou $\left(40^{\circ} 22^{\prime} \mathrm{N}, 116^{\circ} 1^{\prime} \mathrm{E}\right)$, Beijing, China. The animals were kept in an enclosed animal house and the mean minimum and maximum room temperatures observed during the experimental period were 15.5 and $26.5{ }^{\circ} \mathrm{C}$ (average $21.0{ }^{\circ} \mathrm{C}$ ), respectively.

\section{Animals, treatments, and experimental procedure}

Thirty-five Dorper $\times$ thin-tailed Han crossbred male lambs weaned at approximately $50 \mathrm{~d}$ of age with 20.4 $\pm 2.15 \mathrm{~kg} \mathrm{BW}$ were used in a completely randomized design to measure protein requirements for maintenance and growth. The experimental diet was formulated according to NRC [4] with a concentrate-to-forage ratio of $44: 56$ on a dry matter (DM) basis (Table 1$)$. The lambs with ad libitum intake were fed once daily at $0800 \mathrm{~h}$ and allowed $10 \%$ of refusals. The amount of feed provided to the restricted feed intake groups was adjusted daily based on the average DM intake (DMI) of the ad libitum group from the previous day. Feed and refusals were sampled daily and frozen at $-20^{\circ} \mathrm{C}$ until analysis.

Table 1 Ingredient and chemical compositions of the pelleted mixture diet

\begin{tabular}{ll}
\hline Items & Value, \%DM \\
\hline Ingredients, DM basis & 55.0 \\
Milled Chinese wildrye hay & 29.4 \\
Cracked corn grain & 14.0 \\
Soybean meal & 0.86 \\
Dicalcium phosphate & 0.50 \\
Salt & 0.24 \\
Mineral/vitamin premix ${ }^{a}$ & \\
Chemical composition & 8.89 \\
ME, MJ/kg DM & 95.5 \\
DM, \% as fed & 11.9 \\
CP, \% of DM & 2.71 \\
EE, \% of DM & 6.32 \\
Ash, \% of DM & 40.9 \\
NDF, \% of DM & 15.2 \\
ADF, \% of DM & 0.68 \\
Calcium, \% of DM & 0.33 \\
Phosphorus, \% of DM
\end{tabular}

${ }^{\mathrm{a} M a n u f a c t u r e d ~ b y ~ P r e c i s i o n ~ A n i m a l ~ N u t r i t i o n ~ R e s e a r c h ~ C e n t r e, ~ B e i j i n g, ~ C h i n a . ~}$ The premix contained (per kg): $22.1 \mathrm{~g} \mathrm{Fe}, 13.0 \mathrm{~g} \mathrm{Cu}, 30.2 \mathrm{~g} \mathrm{Mn}, 77.2 \mathrm{~g} \mathrm{Zn}$, $19.2 \mathrm{~g} \mathrm{Se}, 53.5 \mathrm{~g} \mathrm{l}, 9.10 \mathrm{~g} \mathrm{Co}, 56.0 \mathrm{~g}$ vitamin $\mathrm{A}, 18.0 \mathrm{~g}$ vitamin $\mathrm{D}_{3}$, and $170 \mathrm{~g}$ vitamin $\mathrm{E}$
A comparative slaughter trial was conducted as described previously [9]. Briefly, the initial body composition was measured on seven lambs slaughtered at $20 \mathrm{~kg} \mathrm{BW}$ (baseline group). An intermediate slaughter group with seven randomly selected lambs fed ad libitum were slaughtered at $28.6 \mathrm{~kg} \mathrm{BW}$. The remaining 21 lambs were randomly assigned to three levels of DMI: ad libitum or $70 \%$ or $40 \%$ of ad libitum intake. Thus, the lambs were pair-fed in seven slaughter groups, with each group consisting of one lamb from each level of intake. When the lambs fed ad libitum of each slaughter group reached $35 \mathrm{~kg} \mathrm{BW}$, all lambs within a slaughter group were fasted and slaughtered. Seven lambs in the baseline and intermediate group were slaughtered in one day, respectively, while the remaining 21 lambs were slaughtered in three consecutive days. All lambs were slaughtered by exsanguination after stunning by $\mathrm{CO}_{2}$ inhalation. Blood, carcass, head, feet, hide, wool, viscera, and adipose tissue removed from the internal organs were weighed. The empty body weight (EBW) was calculated by subtracting the weight of the digestive tract contents from the shrunk BW (SBW), which was measured as BW after a 16-h fast of feed and water. Carcasses and heads were split longitudinally into two identical halves and the muscle, bone, and fat were dissected from the right-half carcass, head, and feet, while the whole hide and whole viscera were ground and homogenized separately and frozen at $-20{ }^{\circ} \mathrm{C}$ until analysis. Wool was clipped with electrical clippers after slaughter, and subsamples were collected and stored at $4{ }^{\circ} \mathrm{C}$.

\section{Chemical analyses}

Feed and orts were oven-dried at $55{ }^{\circ} \mathrm{C}$ for $72 \mathrm{~h}$, ground to pass through a $1-\mathrm{mm}$ screen for analyzing DM (method 930.15) [10], ash (method 924.05) [10], ether extract (EE) (method 920.85) [10], and nitrogen $(\mathrm{N})$ [11]. The gross energy (GE) of feed was measured with a bomb calorimeter (C200, IKA Works Inc., Staufen, Germany). The neutral detergent fiber (NDF) and acid detergent fiber (ADF) of feed were measured according to Van Soest et al. [12] and Goering and Van Soest [13], respectively. Calcium of feed was analyzed using an atomic absorption spectrophotometer (M9W-700, Perkin-Elmer Corp., Norwalk, CT, USA) (method 968.08) [10]. The total $\mathrm{P}$ of feed was analyzed by the molybdovanadate colorimetric method (method 965.17) [10] using a spectrophotometer (UV6100, Mapada Instruments Co., Ltd., Shanghai, China).

The DM of all body components except wool was determined following lyophilization for $72 \mathrm{~h}$ to constant weight. The samples were then analyzed for $\mathrm{N}$ as 
described above. Wool samples were cut into 2-mm pieces with scissors and analyzed for $\mathrm{N}$ as described above.

\section{Data calculations}

Metabolizable protein supply: The ratio of metabolizable protein (MP) to $\mathrm{OM}$ intake reported in a previous in vivo study (i.e., 69.4, 88.9, and 102.4 g $\mathrm{MP} / \mathrm{kg} \mathrm{OM}$ intake for ad libitum, $70 \%$ and $50 \%$ of the ad libitum intake, respectively) [14] with Dorper $\times$ thin-tailed Han crossbred sheep subjected to the same feeding regime as the present study was used to calculate the individual MP intake (MPI) by the ram lambs.

Prediction of the initial body $\mathrm{N}$ content and $\mathrm{N}$ retention (NR): The NR in the body of the lambs in the comparative slaughter trial was calculated as the difference between the final and initial body $\mathrm{N}$ content. The initial body $\mathrm{N}$ content of each animal was calculated from its initial EBW using a regression equation developed from the relationship between the body $\mathrm{N}$ content and EBW of the baseline animals $\left(R^{2}=0.92\right.$, root mean square error $[$ RMSE] $=0.011, \mathrm{n}=7, P<0.001): \log _{10}$ empty body

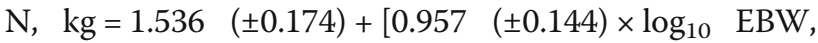
$\mathrm{kg}$. The initial SBW of each animal was computed from its initial BW $\left(R^{2}=0.97\right.$, RMSE $\left.=0.280, \mathrm{n}=7\right)$ : SBW, $\mathrm{kg}$ $=0.571( \pm 1.457)+[0.915( \pm 0.069) \times \mathrm{BW}, \mathrm{kg}]$, and the initial EBW of each animal was computed from its initial BW $\left(R^{2}=0.86, \quad R M S E=0.429, \mathrm{n}=7\right): E B W, \mathrm{~kg}=2.336$ $( \pm 2.227)+[0.695( \pm 0.105) \times \mathrm{BW}, \mathrm{kg}]$.

Protein requirements for maintenance: A linear regression of daily $\mathrm{NR}$ on daily $\mathrm{N}$ intake (NI) was used to calculate the net protein (NP) requirement for maintenance. The intercept of the regression was assumed the endogenous and metabolic losses of $\mathrm{N}$ multiplied by the factor 6.25, which is assumed the maintenance requirement for NP $\left(\mathrm{NP}_{\mathrm{m}}, \mathrm{g} / \mathrm{kg}^{0.75} \mathrm{SBW}\right)$. The MP required for maintenance $\left(\mathrm{MP}_{\mathrm{m}}, \mathrm{g} / \mathrm{kg}^{0.75} \mathrm{SBW}\right)$ was then estimated by regressing the NR on MPI and extrapolating the linear regression to zero NR. The efficiency of MP use for maintenance $\left(\mathrm{k}_{\mathrm{pm}}\right)$ was computed as $\mathrm{NP}_{\mathrm{m}} / \mathrm{MP}_{\mathrm{m}}$.

Protein requirements for growth: The NP requirements for body weight gain $\left(\mathrm{NP}_{\mathrm{g}}\right)$ were calculated as the difference between body protein content at different intervals. For example, the $\mathrm{NP}_{\mathrm{g}}$ of a lamb with $20 \mathrm{~kg} \mathrm{SBW}$ and $250 \mathrm{~g}$ of average daily gain (ADG) was computed as the difference between body protein contents at 20.25 and $20 \mathrm{~kg} \mathrm{SBW}$. Body protein contents were predicted from EBW using an allometric equation according to ARC (1980): $\log _{10}$ protein, $\mathrm{kg}=\mathrm{a}+\left[\mathrm{b} \times \log _{10} \mathrm{EBW}, \mathrm{kg}\right]$. To estimate the partial efficiencies of MP use for body weight gain $\left(\mathrm{k}_{\mathrm{pg}}\right)$, a regression model through the origin was used to partition the utilization of MPI above maintenance for body protein retention as follows: $\mathrm{MPI}_{\mathrm{g}}=$ $\mathrm{b} \times \mathrm{RP}$, where MPI $\left(\mathrm{g} / \mathrm{kg}^{0.75}\right.$ of SBW) is the MPI above maintenance calculated as the difference between the total MPI and $\mathrm{MP}_{\mathrm{m}}, \mathrm{RP}\left(\mathrm{g} / \mathrm{kg}^{0.75}\right.$ of SBW) is the daily retention of body protein, and the estimated parameter $\mathrm{b}$ is the amount of MP $(\mathrm{g})$ required to retain $1 \mathrm{~g}$ of protein, and its inverse was assumed to be $\mathrm{k}_{\mathrm{pg}}$.

\section{Statistical analyses}

The data were analyzed as a completely randomized design using the SAS statistical software package (version 9.1; SAS Institute, Inc., Cary, NC). Intake, body composition, and growth rate were analyzed using a one-way ANOVA. Pairwise comparisons of means were performed by Tukey's multiple range tests once the significance of the treatment effect was declared at $P<0.05$. The statistical model is: $y_{i j}=\mu+\alpha_{i}+\varepsilon_{i j}$, where $y_{i j}=$ dependent variable, $\mu=$ overall mean of Yij, $\alpha_{i}=$ effect of the diet ( $\mathrm{i}=1$ to 3 ), and $\varepsilon_{i j}=$ error contribution. Linear regressions were conducted with a GLM, and observations with a studentized residual $>2.5$ or $<-2.5$ were considered outliers. The assumptions of the models, in terms of homoscedasticity, independency, and normality of errors, were examined by plotting residuals against the predicted values.

\section{Results}

The intake of $\mathrm{OM}$ and $\mathrm{N}$ increased with feeding level $(P<0.001$; Table 2). The lambs fed with ad libitum intake retained greater $\mathrm{N}$ than those with either level of restricted feed intake $(P<0.001)$. The lambs fed at $40 \%$ of the ad libitum intake had a lower MPI than those in the other two groups $(P<0.001)$, and the MPI did not differ between lambs fed at ad libitum and $70 \%$ of the ad libitum intake $(P=0.286)$.

Table 2 Daily protein intake of Dorper $\times$ thin-tailed Han crossbred ram lambs at ad libitum (AL) or restricted to $70 \%$ or $40 \%$ of $\mathrm{AL}$ intake ${ }^{1}$

\begin{tabular}{|c|c|c|c|c|c|}
\hline \multirow[b]{2}{*}{ Items } & \multicolumn{3}{|c|}{ Level of feed intake ${ }^{2}$} & \multirow[t]{2}{*}{ SEM } & \multirow[t]{2}{*}{$P^{4}$} \\
\hline & $\mathrm{AL}$ & $70 \%$ & $40 \%$ & & \\
\hline$\overline{A D G}, \mathrm{~g}$ & $324.2^{a}$ & $189.1^{b}$ & $37.6^{c}$ & 19.3 & $<0.001$ \\
\hline Initial SBW, kg & 19.3 & 19.5 & 18.5 & 0.22 & 0.271 \\
\hline Final SBW, kg & $29.9^{a}$ & $27.8^{\mathrm{a}}$ & $20.4^{b}$ & 0.91 & $<0.001$ \\
\hline OM intake, g/d & $107.6^{a}$ & $84.2^{b}$ & $53.3^{c}$ & 4.37 & $<0.001$ \\
\hline $\begin{array}{l}\mathrm{N} \text { intake, } \\
\mathrm{g} /\left(\mathrm{kg} \mathrm{SBW}^{0.75} \cdot \mathrm{d}\right)\end{array}$ & $1.83^{\mathrm{a}}$ & $1.43^{b}$ & $1.01^{\mathrm{c}}$ & 0.08 & $<0.001$ \\
\hline $\begin{array}{l}\mathrm{N} \text { retention, } \\
\mathrm{g} /\left(\mathrm{kg} \mathrm{SBW}{ }^{0.75} \cdot \mathrm{d}\right)\end{array}$ & $0.47^{a}$ & $0.29^{b}$ & $0.11^{c}$ & 0.03 & $<0.001$ \\
\hline $\begin{array}{l}\text { MP intake, } \\
\mathrm{g} /\left(\mathrm{kg} \mathrm{SBW}^{0.75} \cdot \mathrm{d}\right)^{3}\end{array}$ & $7.47^{\mathrm{a}}$ & $7.49^{\mathrm{a}}$ & $5.46^{c}$ & 0.18 & $<0.001$ \\
\hline
\end{tabular}

${ }^{1}$ ADG: average daily gain; SBW: shrunk body weight; MP:

metabolizable protein

${ }^{2}$ Ad libitum or restricted to $70 \%$ or $40 \%$ of ad libitum of an identical diet

${ }^{3}$ Calculated from the ratio of MP supply to OM intake reported by Ma et al. [14]

$4 \mathrm{a}, \mathrm{b}, \mathrm{c}$ Means bearing different superscripts differ $(P<0.05)$ 
Figure 1 shows the linear relationship between NR and $\mathrm{NI}: \quad \mathrm{NR}, \quad \mathrm{g} /\left(\mathrm{kg} \mathrm{SBW}^{0.75} \cdot \mathrm{d}\right)=-0.303( \pm 0.046)+[0.422$ $( \pm 0.040) \times \mathrm{N}$ intake, $\left.\mathrm{g} /\left(\mathrm{kg} \mathrm{SBW}{ }^{0.75} \cdot \mathrm{d}\right)\right]\left(R^{2}=0.89\right.$, RMSE $=0.054, \mathrm{n}=28, P<0.001)$. The endogenous and metabolic loss of $\mathrm{N}$, estimated as the intercept of the linear regression, was $303 \pm 46 \mathrm{mg} / \mathrm{kg}^{0.75} \mathrm{SBW}$, which corresponds to an $\mathrm{NP}_{\mathrm{m}}$ of $1.89 \pm 0.29 \mathrm{~g} / \mathrm{kg}^{0.75} \mathrm{SBW}$.

Figure 2 shows the linear relationship between NR and MPI: NR, g/(kg SBW $\left.{ }^{0.75} \cdot \mathrm{d}\right)=-0.628( \pm 0.138)+[0.139$ $\left.( \pm 0.020) \times \mathrm{MPI}, \mathrm{g} /\left(\mathrm{kg} \mathrm{SBW}{ }^{0.75} \cdot \mathrm{d}\right)\right], R^{2}=0.70, \quad \mathrm{RMSE}=$ $0.096, \mathrm{n}=28, P<0.001)$. The MP required for maintenance by extrapolating the linear regression to zero $\mathrm{N}$ retention was $4.52 \mathrm{~g} / \mathrm{kg}^{0.75} \mathrm{SBW}$. Consequently, the $\mathrm{k}_{\mathrm{pm}}$ was 0.42 for Dorper $\times$ thin-tailed Han crossbred male lambs from 20 to $35 \mathrm{~kg}$ of BW.

The partial efficiencies of MP use for body weight gain were estimated using a regression model and assuming that the MPI above maintenance $\left(\mathrm{MPI}_{\mathrm{g}}\right)$ is partially recovered as body protein for growth $\left(\mathrm{PR}_{\mathrm{g}}, \mathrm{g} /\right.$ $\mathrm{kg}^{0.75}$ of $\left.\mathrm{SBW}\right)$. The regression equation was: $\mathrm{PR}_{\mathrm{g}}, \mathrm{g} /$ $\left(\mathrm{kg}^{0.75} \mathrm{SBW} \cdot \mathrm{d}\right)=0.002( \pm 0.052)+[0.864 \pm 0.123) \times \mathrm{MPI}_{\mathrm{g}}, \mathrm{g} /$ $\left(\mathrm{kg}^{0.75}\right.$ of SBW $\left.\left.\cdot \mathrm{d}\right)\right]\left(R^{2}=0.70, \mathrm{n}=28, \mathrm{RMSE}=0.081\right)$. The slope of the regression equation (0.86) represents $\mathrm{k}_{\mathrm{pg}}$.

The allometric equation between body protein and EBW $\left(R^{2}=0.96\right.$; $\left.\mathrm{RMSE}=0.012 ; \mathrm{n}=20\right)$ of the ram lambs with free consumption of feed was proposed as $\log _{10}$ protein, $g=2.385( \pm 0.072)+\left[0.922( \pm 0.054) \times \log _{10}\right.$ EBW, kg] The $\mathrm{NP}_{\mathrm{g}}$ and $\mathrm{MP}$ for growth $\left(\mathrm{MP}_{\mathrm{g}}\right)$ were therefore calculated accordingly (Tables 3 and 4).

\section{Discussion}

The $\mathrm{NP}_{\mathrm{m}}$ is the quantity of protein to sustain tissue proteins by counterbalancing the inevitable losses of urinary, fecal, and dermal N [3]. AFRC [15] suggested daily endogenous and metabolic $\mathrm{N}$ losses of $350 \mathrm{mg} / \mathrm{kg}$ $\mathrm{BW}^{0.75}$ for lambs nourished by intra-gastric infusions. However, this method might overestimate the endogenous $\mathrm{N}$ requirement due to the lack of conservation of

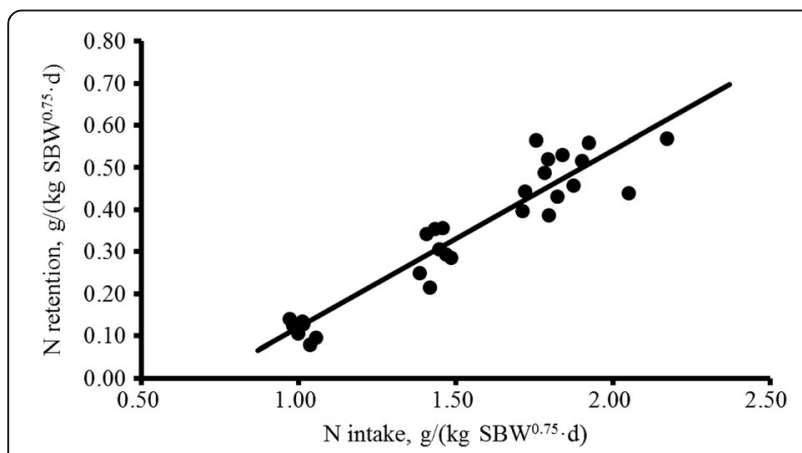

Fig. 1 Relationship between $\mathrm{N}$ retention (NR) and $\mathrm{N}$ intake (NI) of Dorper $\times$ thin-tailed Han crossbred male lambs from 20 to $35 \mathrm{~kg}$ of BW. NR, g/kg SBW ${ }^{0.75}=-0.303( \pm 0.046)+[0.422( \pm 0.040) \times \mathrm{NI}, \mathrm{g} / \mathrm{kg}$ of $\left.\mathrm{SBW}^{0.75}\right], R^{2}=0.89, \mathrm{RMSE}=0.054, \mathrm{n}=28$

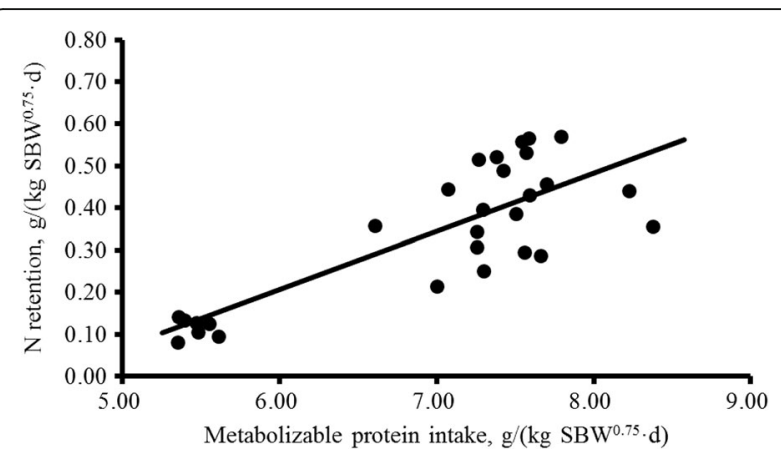

Fig. 2 Relationship between $\mathrm{N}$ retention (NR) and metabolizable protein intake (MPI) of Dorper $\times$ thin-tailed Han crossbred male lambs from 20 to $35 \mathrm{~kg}$ of BW. NR, g/kg SBW ${ }^{0.75}=-0.628( \pm 0.138)$ $+\left[0.139( \pm 0.020) \times \mathrm{MPI}, \mathrm{g} / \mathrm{kg} \mathrm{SBW}^{0.75}\right], R^{2}=0.70, \mathrm{RMSE}=0.096, \mathrm{n}=28$

protein by the microbial capture of N. CSIRO [3] suggested the $\mathrm{NP}_{\mathrm{m}}$ of the sheep is the sum of the endogenous urinary loss $(0.147 \times \mathrm{BW}+3.375)$ and fecal loss (15.2 $\mathrm{g} / \mathrm{kg} \mathrm{DM}$ intake). Thus, the $\mathrm{NP}_{\mathrm{m}}$ for a lamb of $28 \mathrm{~kg}$ consuming $1.02 \mathrm{~kg}$ of DM daily (this is the average DM intake of the 28 lambs used in the current study) is about $23.0 \mathrm{~g}$, which is $10 \%$ higher than the current value $\left(1.72 \mathrm{~g} / \mathrm{kg} \mathrm{BW}^{0.75}\right)$. In the current study, the $\mathrm{NP}_{\mathrm{m}}$ calculated by partial regression NR on NI $\left(1.72 \mathrm{~g} / \mathrm{kg} \mathrm{BW}^{0.75}\right.$ or $1.89 \mathrm{~g} / \mathrm{kg} \mathrm{SBW}{ }^{0.75}$ ) is slightly higher than that of the Ile de France $\left(1.56 \mathrm{~g} / \mathrm{kg} \mathrm{SBW}^{0.75}\right)$ [16] and Texel crossbreeds $\left(1.52 \mathrm{~g} / \mathrm{kg} \mathrm{SBW}^{0.75}\right)$ [17], but lower than that of Morada Nova $\left(1.83 \mathrm{~g} / \mathrm{kg} \mathrm{BW}^{0.75}\right)$ [18] male lambs measured using the same methods. The lambs fed at the maintenance level had similar NR (around 0.1 to $0.2 \mathrm{~g} / \mathrm{kg}$ of $\mathrm{SBW}^{0.75}$ ) among all these studies. However, when fed higher than the maintenance level, Dorper crossbred had a relatively higher NR $\left(0.25\right.$ to $0.65 \mathrm{~g} / \mathrm{kg}$ of $\left.\mathrm{SBW}^{0.75}\right)$ than the Ile de France [16] and Texel crossbreeds [17], but a lower NR than Morada Nova lambs $(0.25$ to $1.0 \mathrm{~g} / \mathrm{kg}$ of $\mathrm{BW}^{0.75}$ ) [18]. Therefore, the variations in $\mathrm{NP}_{\mathrm{m}}$ can be explained by the differential utilization efficiency of protein or amino acids by the tissues during the growth of lambs. On the other hand, the above studies were all conducted in a tropical or sub-tropical zone with high humidity, while the current study was conducted in a warm

Table 3 Requirements of net protein (NP) for growth $(\mathrm{g} / \mathrm{d})$ of Dorper $\times$ thin-tailed Han crossbred male lambs from 20 to $35 \mathrm{~kg}$ of body weight (BW)

\begin{tabular}{|c|c|c|c|c|}
\hline \multirow{2}{*}{$\begin{array}{l}\text { ADG, } \\
\mathrm{g} / \mathrm{d}\end{array}$} & \multicolumn{4}{|c|}{ BW, kg } \\
\hline & 20 & 25 & 30 & 35 \\
\hline 100 & 12.4 & 12.3 & 12.2 & 12.1 \\
\hline 200 & 24.9 & 24.6 & 24.4 & 24.2 \\
\hline 300 & 37.3 & 36.9 & 36.6 & 36.3 \\
\hline 350 & 43.5 & 43.0 & 42.7 & 42.3 \\
\hline
\end{tabular}

ADG: average daily gain 
Table 4 Requirements of metabolizable protein (MP) for growth ( $\mathrm{g} / \mathrm{d})$ of Dorper $\times$ thin-tailed Han crossbred male lambs from 20 to $35 \mathrm{~kg}$ of body weight (BW)

\begin{tabular}{|c|c|c|c|c|}
\hline \multirow{2}{*}{$\begin{array}{l}\text { ADG, } \\
\mathrm{g} / \mathrm{d}\end{array}$} & \multicolumn{4}{|c|}{ BW, kg } \\
\hline & 20 & 25 & 30 & 35 \\
\hline 100 & 14.4 & 14.3 & 14.2 & $\overline{14.1}$ \\
\hline 200 & 29.0 & 28.6 & 28.4 & 28.1 \\
\hline 300 & 43.4 & 42.9 & 42.6 & 42.2 \\
\hline 350 & 50.6 & 50.0 & 49.7 & 49.2 \\
\hline
\end{tabular}

ADG: average daily gain

temperate zone where the weather is always dry during summer. As reviewed by Marai et al. [19], both temperature and humidity could have influence on nutrient digestibility and degradation in the rumen; thus, the experimental condition could be another important factor that contributes to the differences in $\mathrm{NP}_{\mathrm{m}}$ apart from methods or animal breeds. We concluded that $1.69 \mathrm{~g} / \mathrm{kg}$ $\mathrm{BW}^{0.75}$ or $1.81 \mathrm{~g} / \mathrm{kg} \mathrm{SBW}^{0.75}$ is suitable for the $\mathrm{NP}_{\mathrm{m}}$ of Dorper crossbred male lambs from 20 to $35 \mathrm{~kg}$ of BW.

The $\mathrm{MP}_{\mathrm{m}}$ obtained in the current study was $4.52 \mathrm{~g} / \mathrm{kg}$ $\mathrm{SBW}^{0.75}$. When scaled to $\mathrm{BW}$, our value $(4.37 \mathrm{~g} / \mathrm{kg}$ $\mathrm{BW}^{0.75}$ ) was close to Liu et al. [20], who found an $\mathrm{MP}_{\mathrm{m}}$ of $4.41 \mathrm{~g} / \mathrm{kg} \mathrm{BW}^{0.75}$ from a linear multiple regression of MP requirements against the live weight, live weight gain, and wool growth of sheep $(n=213)$ in a feeding study. Nevertheless, our result is greater than that suggested by AFRC $\left(2.19 \mathrm{~g} / \mathrm{kg} \mathrm{BW}^{0.75}\right)$ [2], INRA (2.50 g/ $\mathrm{kg}$ $\left.\mathrm{BW}^{0.75}\right)[21]$, or NRC $\left(3.72 \mathrm{~g} / \mathrm{kg} \mathrm{BW}^{0.75}\right)$ [22]. In a more recent study, where a comparative slaughter trial was also used, a $\mathrm{MP}_{\mathrm{m}}$ of $2.31 \mathrm{~g} / \mathrm{kg} \mathrm{SBW}^{0.75}$ was observed in Texel crossbred lambs [17]. The methods adopted by UK [2], Australia [3], USA [4], and France [21] were all based on a common overall model, although requirements were expressed in different terms. In the current study, MP was calculated based on the method reported by Ma et al. [14], who conducted an in vivo study and measured MP using sheep with ruminal and duodenal cannula. Therefore, the discrepancy in the calculation of MP is inevitably associated with the methodologies adopted. As there is still a lack of simple and robust methods for calculating MP, this area requires further investigation and examination.

The $\mathrm{NP}_{\mathrm{g}}$ values $(12.4,24.9$, and $37.3 \mathrm{~g} / \mathrm{d})$ determined in the current study are extensively lower than those of early maturing growing lambs $(23.5,30.5$, and $50.0 \mathrm{~g} / \mathrm{d})$ of $20 \mathrm{~kg} \mathrm{BW}$ gaining 100, 200, and $300 \mathrm{~g} / \mathrm{d}$ recommended by NRC [4], assuming a $\mathrm{k}_{\mathrm{pg}}$ of 0.50 . AFRC [2] used two equations proposed by ARC [23], $\mathrm{NP}_{\mathrm{f}}(\mathrm{g} / \mathrm{d})=$ $\mathrm{ADG} \times\left(160.4-1.22 \times \mathrm{BW}+0.0105 \times \mathrm{BW}^{2}\right)$ and $\mathrm{NP}_{\mathrm{w}}$ $(\mathrm{g} / \mathrm{d})=3+0.1 \times \mathrm{NP}_{\mathrm{f}}$, where $\mathrm{NP}_{\mathrm{f}}$ is the NP requirement for fleece-free body growth and $\mathrm{NP}_{\mathrm{w}}$ is the NP requirement for wool growth, to predict the protein requirement for the growth of body and fleece in lambs, respectively. Using those equations, the $\mathrm{NP}_{\mathrm{g}}\left(\mathrm{NP}_{\mathrm{f}}+\mathrm{NP}_{\mathrm{w}}\right)$ was approximately $26 \%$ to $49 \%$ higher (range from 17.4 to $57.0 \mathrm{~g} / \mathrm{d}$ ) than values determined in the current study. Therefore, caution should be taken before applying certain evaluation systems to avoid the overestimation of $\mathrm{NP}_{\mathrm{g}}$ of Dorper crossbred lambs. By using the same method, our $\mathrm{NP}_{\mathrm{g}}$ results were $26 \%$ higher than those of the Texel crossbreed [17] growing from 20 to $35 \mathrm{~kg}$ of SBW gaining 100 and $200 \mathrm{~g} / \mathrm{d}$, but $20 \%$ lower than that of Morada Nova lambs [18] growing from 20 to $30 \mathrm{~kg}$ of BW gaining 100, 200, and $300 \mathrm{~g} / \mathrm{d}$, respectively. Although the ME (0.76 vs. $\left.0.73 \mathrm{MJ} / \mathrm{kg} \mathrm{SBW}^{0.75}\right)$, NI (2.12 vs. $\left.2.20 \mathrm{~g} / \mathrm{kg} \mathrm{SBW}^{0.75}\right)$, and $\mathrm{N}$ retention/ $\mathrm{N}$ intake $(26.1 \%$ vs. $25.9 \%)$ were close, the ADG of ad libitum groups were much higher for the Dorper crossbred (324 g) than Texel crossbred (245 g) lambs reported by Galvani et al. [17]. Many factors could be associated with such discrepancies, including breed, physiological stage, and experimental conditions.

The partial efficiency of use of $\mathrm{MP}_{\mathrm{m}}$ for $\mathrm{NP}_{\mathrm{m}}\left(\mathrm{k}_{\mathrm{pm}}\right)$ was calculated to be 0.42 in the present study. This value is lower than previously adopted 1.0 by AFRC [15] or 0.67 by CSIRO [3], as well as lower than that of Texel crossbred lambs (0.66) [17]. The partial efficiency of use of $\mathrm{MP}_{\mathrm{g}}$ for $\mathrm{NP}_{\mathrm{g}}\left(\mathrm{k}_{\mathrm{pg}}\right)$ obtained in the current study (0.86) was greater than that adopted by AFRC (0.59) [2], CSIRO (0.70) [3] and by Galvani et al. [17] in Texel crossbred lambs (0.71). Those discrepancies could be attributed to animal factors, including breed, maturity, and physiological status. The method for calculating or determining MP may be another factor contributing to the variability of the efficiency of MP use. NRC [4] suggested a simple equation, $\mathrm{MP}=\mathrm{CP} \times(0.64+0.16 \times \% \mathrm{UDP}) /$ 100 , where UDP is undegraded dietary protein, to convert $\mathrm{CP}$ to $\mathrm{MP}$. By using this equation, $\mathrm{MP} / \mathrm{CP}$ was 0.72 in all treatments, and $\mathrm{k}_{\mathrm{pm}}$ and $\mathrm{k}_{\mathrm{pg}}$ were $0.59(1.89 / 3.22)$ and 0.58 , respectively. Our previous study showed that a decreased feed intake could increase total-tract $\mathrm{N}$ digestibility without affecting ruminal $\mathrm{N}$ degradability [24], and the increased duodenal $\mathrm{N}$ digestibility could be due to the prolonged gastric empty time. Thus, it could not be expected that $\mathrm{MP} / \mathrm{CP}$ were identical under a different feeding level. In the current study, MP was calculated from OM intake based on the results of our previous study using 6-month-old Dorper $\times$ thin-tailed Han male lambs $(41.3 \pm 2.8 \mathrm{~kg} \mathrm{BW})$ with both ruminal and duodenal cannula fed at three different levels (ad libitum, $70 \%$, and $50 \%$ of ad libitum) in which MP supply/OM intake $(\mathrm{g} / \mathrm{kg})$ was $69.4,88.9$, and 102.4 , respectively. As there is still lack of a simple method for the calculation of MP, this could be a reasonable way to calculate MP in the current study. Nevertheless, considering the difference in animal physiology status (BW, age, and cannulation) between our previous and current studies, further 
study is still needed to examine the utilization efficiency of MP for both the maintenance and growth for earlyweaning lambs.

\section{Conclusions}

In conclusion, the current study suggested that the protein requirements for the maintenance and growth of Dorper $\times$ thin-tailed Han early-weaned crossbred male lambs were lower than the recommendations of AFRC (1993) and NRC (2007).

\section{Abbreviations}

ADF: Acid detergent fiber; ADG: Average daily gain; CP: Crude protein; DM: Dry matter; EBW: Empty body weight; EE: Ether extract; GE: Gross energy; ME: Metabolizable energy; $\mathrm{MNI}_{\mathrm{g}}$ : Metabolizable $\mathrm{N}$ intake above maintenance; MP: Metabolizable protein; $\mathrm{MP}_{\mathrm{g}}$ : MP requirements for body weight gain; $\mathrm{MPI}$ g: MP intake above maintenance; $\mathrm{MP}_{\mathrm{m}}$ : Metabolizable protein for maintenance; N: Nitrogen; NDF: Neutral detergent fiber; NP: Net protein; $N P_{f}$ : Net protein requirements for fleece-free body growth; $N P_{g}$ : Net protein requirements for body weight gain; $\mathrm{NP}_{\mathrm{m}}$ : Net protein for maintenance; $\mathrm{NP}_{\mathrm{w}}$ : Net protein requirements for wool growth; NR: Nitrogen retention; OM: Organic matter; RMSE: Root mean square error; $\mathrm{RN}_{\mathrm{g}}$ : Body N for growth; SBW: Shrunk body weight; UDP: Undegraded dietary protein

\section{Acknowledgements}

We thank the staff (Y.L. Li, Y.F. Zhang, J. Liu, Y.G. Zhao, S.K. Ji, L.T. Zhang, and C. Lou) of Feed Research Institute of Chinese Academy of Agricultural Sciences for their technical assistance.

\section{Funding}

This research was supported by the earmarked fund for the China Agriculture Research System (CARS-39). This manuscript was a part of the 1st International Symposium on Young Ruminant (ISYR)-Physiology and Rearing Strategies jointly organised by Laboratory of Ruminant Physiology and Nutrition, Feed Research Institute, Chinese Academy of Agricultural Sciences, China, The Pennsylvania State University, US, Agri-Food and Biosciences Instute, UK, Beijing Dairy Industry Innovation Consortium of Agriculture Research System, Beijing Key Laboratory for Dairy Nutrition.

\section{Availability of data and materials}

Data sharing not applicable to this article as no datasets were generated or analyzed during the current study.

\section{Authors' contributions}

GX carried out the whole animal experiment, including sample collection and determination. TM participated in the statistical analysis and wrote the draft. KD helped to revise the manuscript. YT, NZ, and BS participated in the design and coordination of the study. QD conceived of the study. All authors read and approved the final manuscript.

\section{Competing interest}

The authors declare that they have no competing interest.

\section{Consent for publication}

Not applicable.

\section{Ethics approval}

The experimental protocol was approved by the CAAS Animal Ethical Committee, and humane animal care and handling procedures were followed throughout the experiment.

\section{Author details}

${ }^{1}$ Feed Research Institute/Key laboratory of Feed Biotechnology of the Ministry of Agriculture, Chinese Academy of Agricultural Sciences, Beijing, China. ${ }^{2}$ College of Animal Science, Jinling Institute of Technology, Nanjing, Jiangsu, China. ${ }^{3}$ College of Animal Science, Tarim University, Alar, Xinjiang, China.
Received: 25 October 2016 Accepted: 13 April 2017

Published online: 01 May 2017

\section{References}

1. Ma T, Xu GS, Deng KD, Ji SK, Tu Y, Zhang NF, et al. Energy requirements of early-weaned Dorper cross-bred female lambs. J Anim Physiol An N. 2016. doi:10.1111/jpn.12480

2. AFRC. Energy and protein requirements of ruminants. An advisory manual prepared by the Agricultural and Food Research Council Technical Committee on Responses to Nutrients. Wallingford: CAB International; 1993.

3. CSIRO. Nutrient requirements of domesticated ruminants. Collingwood: Commonwealth Scientific and Industrial Research Organisation Publishing; 2007.

4. NRC. Nutrient Requirements of Small Ruminants: Sheep, Goats, Cervids, and New World Camelids. Washington: National Academy Press; 2007.

5. Snowder GD, Duckett SK. Evaluation of the South African Dorper as a terminal sire breed for growth, carcass, and palatability characteristics. J Anim Sci. 2003;81(2):368-75.

6. Chu MX, Liu ZH, Jiao CL, He YQ, Fang L, Ye SC, et al. Mutations in BMPR-IB and BMP-15 genes are associated with litter size in Small Tailed Han sheep (Ovis aries). J Anim Sci. 2007:85:598-603.

7. Deng KD, Diao QY, Jiang CG, Tu Y, Zhang NF, Liu J, et al. Energy requirements for maintenance and growth of Dorper crossbred ram lambs. Livest Sci. 2012:150:102-10.

8. Deng KD, Jiang CG, Tu Y, Zhang NF, Liu J, Ma T. Energy requirements of Dorper crossbred ewe lambs. J Anim Sci. 2014;92:2161-9.

9. Xu GS, Ma T, Ji SK, Deng KD, Tu Y, Jiang CG, et al. Energy requirements for maintenance and growth of early-weane d Dorper crossbred male lambs. Livest Sci. 2015;177:71-8.

10. AOAC. Official methods of analysis. 15th ed. Arlington: AOAC International; 1990

11. Marshall CM, Walker AF. Comparison of a short method for Kjeldahl digestion using a trace of selenium as catalyst, with other methods. J Sci Food Agri. 1978;29:940-2.

12. Van Soest PJ, Robertson JB, Lewis BA. Methods for dietary fiber, neutral detergent fiber and non-starch polysaccharides in relation to animal nutrition. J Dairy Sci. 1991;74:3583-97.

13. Goering HG, Van Soest JP. Forage fiber analysis. Agricultural Handbook, vol. 379. Washington: UPSDA; 1970

14. Ma T, Deng KD, Tu Y, Zhang NF, Jiang CG, Liu J, et al. Effect of feed intake on metabolizable protein supply in Dorper $\times$ thin-tailed Han crossbred lambs. Small Rumin Res. 2015;132:133-6.

15. AFRC. Technical committee on responses to nutrients, Report 9. Nutritive Requirements of Ruminant Animals: Protein. Nutrition Abstracts and Reviews. Series B. 1992;62:787-835.

16. Silva AMA, Silva Sobrinho AG, Trindade IACM, Resende KT, Bakke OA. Net requirements of protein and energy for maintenance of wool and hair lambs in a tropical region. Small Rumin Res. 2003:49:165-71.

17. Galvani DB, Pires CC, Kozloski GV, Sanchez LMB. Protein requirements of Texel crossbred lambs. Small Rumin Res. 2009:81:55-62.

18. Costa MRGF, Pereira ES, Silva AMA, Paulino PVR, Mizubuti IY, Pimentel PG, et al. Body composition and net energy and protein requirements of Morada Nova lambs. Small Rumin Res. 2013;114:206-13.

19. Marai IFM, El-Darawany AA, Fadiel A, Abdel-Hafez MAM. Physiological traits as affected by heat stress in sheep-a review. Small Rumin Res. 2007;71(1):112

20. Liu SM, Smith TL, Karlsson LJE, Palmer DG, Besier RB. The costs for protein and energy requirements by nematode infection and resistance in Merino sheep. Livest Prod Sci. 2005:97(2):131-9.

21. INRA. Ruminant nutrition: Recommended allowances and feed tables. Paris: John Libbey \& Co. Ltd; 1989.

22. NRC. Predicting feed intake of food-producing animals. Washington: National Academy Press; 1987.

23. ARC. The Nutrient Requirements of Ruminant Livestock. Slough: Commonwealth Agricultural Bureaux; 1980.

24. Ma T, Deng KD, Jiang CG, Tu Y, Zhang NF, Liu J, et al. The relationship between microbial $N$ synthesis and urinary excretion of purine derivatives in Dorper X thin-tailed Han crossbred sheep. Small Rumin Res. 2013;112:49-55. 